\title{
Land abandonment, landscape, and biodiversity: questioning the restorative character of the forest transition in the Mediterranean
}

\author{
Iago Otero $^{1,2}{ }^{\text {Joan Marull }}{ }^{3}, \underline{\text { Enric Tello }}^{4}$, Giovanna L. Diana $^{3}, \underline{\text { Manel Pons }}^{3}$, Francesc Coll $^{3}$ and Martí Boada $^{2}$
}

\begin{abstract}
The effects of land abandonment on biodiversity have received considerable attention by scholars, but results are far from conclusive. Different cultural traditions of scientists seem to underlie the contrasting ways in which land abandonment is understood. Although the forest transition (FT) framework considers land abandonment as an opportunity for biodiversity conservation, European landscape ecologists characterize it as a threat. We use insights from both traditions to analyze the effects of land abandonment on landscape and biodiversity in a mountain area of metropolitan Barcelona. We do so through an in-depth historical case study covering a period of 160 years. A set of landscape metrics was applied to land-cover maps derived from cadastral cartography to characterize the landscape ecological changes brought about by land abandonment. Cadastral data on land uses were used to understand how landscape ecological changes could be explained by changing socioeconomic activities. Information on past landmanagement practices from semistructured interviews was used to shed light on how peasants shaped the capacity of landscape to host biodiversity. Our results point to a remarkable landscape deterioration along with the disappearance of the peasant land-use mosaics and the ensuing forest expansion. By using insights from landscape ecology in a historically informed manner, we (1) question the alleged relationship between land abandonment and ecosystem recovery; (2) show that the assumed restorative character of the FT is based on the underestimation of the ecological importance of nonforest habitats; and (3) point at a remarkable trade-off between FT and biodiversity in the Mediterranean. Finally, the case study also serves to illustrate some of the strengths and challenges of using historical approaches to land abandonment.
\end{abstract}

Key Words: biodiversity; cultural landscape; forest transition; land abandonment; landscape changes; landscape structure; land-use change; land-use mosaic; Mediterranean; peasant management

\section{INTRODUCTION}

The effects of farmland abandonment on biodiversity have received considerable attention by scholars, but results are far from conclusive. A recent meta-analysis concluded that a study's geographical region, selected metrics, assessed taxa, and conservation focus significantly affect how the effects of farmland abandonment on biodiversity are reported (Queiroz et al. 2014). Although Eurasian studies often focus on the conservation of preabandonment conditions, i.e., biodiversity related to traditional farming, and report mainly negative effects of farmland abandonment on biodiversity, American studies more commonly focus on the conservation of postabandonment ecosystems, i.e., biodiversity related to secondary forests, and report mainly positive effects (Queiroz et al. 2014). Such contrasting results seem to go beyond methodological aspects and instead reflect different cultural models or preanalytical visions of the relationship between humans and biodiversity (Farina et al. 2003).

A paradigmatic example of studies that consider land abandonment as an opportunity for biodiversity conservation is found in the forest transition (FT) framework (Rudel et al. 2005). An FT is defined as a national shift from a shrinking to an expanding forest area as a society undergoes economic development (Mather 1992). For a given country, the FT foresees a period of net forest decline caused by agricultural expansion, followed by a period of net forest recovery as marginal farmland is out-competed by industrialized agriculture, hence abandoned, afforested, or reforested. Overall, the abandonment of farmland and pastureland is considered to foment ecosystem recovery in combination with the implementation of protected areas and other conservation policies (Grau and Aide 2008). Contrastingly, European landscape ecologists tend to characterize land abandonment and afforestation mostly as a threat for biodiversity, because they usually go together with landscape homogenization and have negative consequences for open-habitat species of conservation value (Farina 1997, Preiss et al. 1997). These studies highlight the importance of landscape heterogeneity for biodiversity conservation (Marull et al. 2014) and point to the need to develop optimum management practices for agricultural landscapes (Bignal and McCracken 1996, Atauri and de Lucio 2001).

On the one hand, forest transition studies underestimate the ecological importance of nonforest habitats by restricting their focus exclusively to forest ecosystems (Walker 2012). On the other hand, an excessive insistence on landscape heterogeneity as a management goal might lead scientists to disregard the benefits of regenerating alternative habitats and biodiversity on, at least some, abandoned farmland (Navarro and Pereira 2012). Hence a broader and more inclusive view of the effects of land abandonment on biodiversity is deemed critical to support the management of changing agricultural landscapes (Queiroz et al. 2014).

\footnotetext{
${ }^{1}$ Integrative Research Institute on Transformations of Human-Environment Systems (IRI THESys), Humboldt-Universität zu Berlin, ${ }^{2}$ Institute of Environmental Science and Technology (ICTA), Autonomous University of Barcelona, ${ }^{3}$ Barcelona Institute of Regional and Metropolitan Studies (IERMB), Autonomous University of Barcelona, ${ }^{4}$ Department of Economic History and Institutions, Faculty of Economics and Business, University of Barcelona
} 
Fig. 1. Study area within Europe, Catalonia, and the Barcelona Metropolitan Region. Source: Reprinted from Otero et al. (2013) with permission from Elsevier.

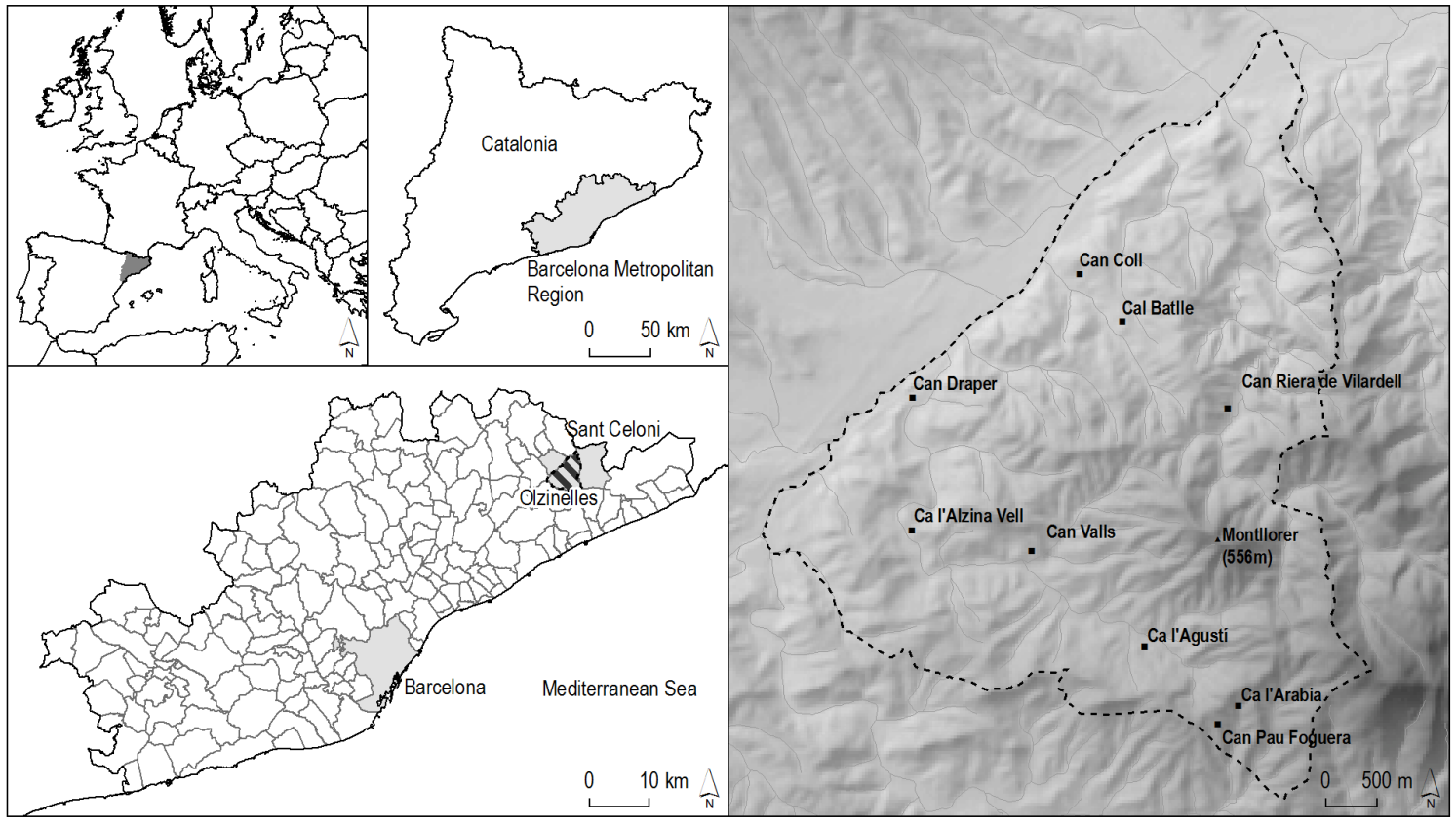

We aim to provide a comprehensive understanding of the effects of land abandonment on landscape and biodiversity. We do so through an in-depth historical case study covering a period of 160 years in a mountain area of the Barcelona metropolitan region. First, a set of landscape metrics is applied to land-cover maps derived from cadastral cartography to characterize the landscape ecological changes brought about by land abandonment. Second, data on land uses and plot features are used to understand how landscape ecological changes can be explained by changing socioeconomic activities. And third, information on past landmanagement practices from semistructured interviews is used to shed light on how peasants shaped landscape structure and its capacity to host biodiversity. Our results point to a remarkable landscape deterioration along with the disappearance of the peasant land-use mosaics once in place and the ensuing forest expansion. The case study also serves to illustrate some of the strengths and challenges of historical approaches to land abandonment. Taking up again the initial reflection on the influence of the conservation focus in the results, it should be acknowledged that we focus on the value of the heterogeneity found in traditional Mediterranean agricultural landscapes shaped by integrated agro-silvo-pastoral land uses throughout history.

\section{STUDY AREA AND METHODS}

\section{Study area}

The Metropolitan Region of Barcelona is located on the northeastern coast of the Iberian Peninsula (Fig. 1). Until the 1950s, diverse agro-silvo-pastoral land-use mosaics structured by a network of small cities, villages, and farmhouses spanned the lowland areas up to the mountain ranges. Later, socioeconomic changes linked to development led to a dramatic transformation of traditional land use and land-cover configurations. Between
1956 and 2000, 14\% of the region experienced urbanization, $10 \%$ afforestation, and 7\% farmland abandonment (Başnou et al. 2013). Our research was conducted in the Montnegre Mountain Range, a coastal range within metropolitan Barcelona. This range was an agricultural frontier during the 18th and 19th centuries, when population growth and an increased demand for cash crops, especially wine, fostered the clearance of forests to establish new farmland. Farmland area peaked by the end of the 19th century, when many vineyards were abandoned and afforested. Our data come from one particular site of the Montnegre Mountain Range, i.e., Olzinelles, $22.87 \mathrm{~km}^{2}$, nowadays belonging to the municipality of Sant Celoni (Fig. 1). In Olzinelles, altitude ranges from 125 to $700 \mathrm{~m}$ a.s.l., mean annual temperature is $14.6^{\circ} \mathrm{C}$, and mean annual rainfall is $703 \mathrm{~mm}$. The landscape is characterized by low granitic hills covered by dense evergreen oak forests. Streams are intermittent. Fauna assemblages from the western Mediterranean are well represented in Olzinelles, where they benefit from a large expanse of dense forest and the presence of indispensable, and nowadays marginal, farmland habitats (Boada 1984). Settlement historically occurred in the form of dispersed farmhouses, which combined subsistence agriculture based on cereals with the exploitation of evergreen oak forests. The population in farmhouses peaked around 1860 at 309 inhabitants, and since 1924 showed a steady decline because farmers abandoned their lands in search of better nonfarm jobs in nearby towns (Fig. 2). Many of the old farmhouses were left and became dilapidated. Instead, new houses were built from the 1960s, initially sold as secondary residences to urban dwellers that later settled permanently. These residential areas are made up of single-family houses, which lack access to basic services and are notably vulnerable to wildfire (Piqueras 2009). About two thirds of our study site is included in the Montnegre-Corredor Natural Park, which was incorporated into the Natura 2000 network. 
Fig. 2. Demographic evolution of Olzinelles (1842-2007). Source: Reprinted from Otero et al. (2013) with permission from Elsevier. Note: Masos are the traditional farmhouses of the Catalan countryside. Housing development refers to residential houses built from the 1960s. The total population of the study area is the sum of both curves.

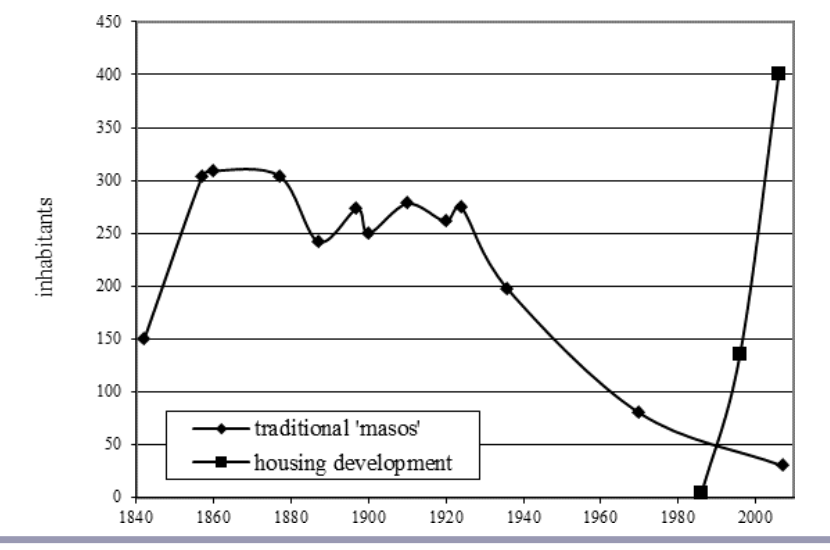

\section{Methods}

The case study approach was chosen because it allows for a longterm, multievidentiary strategy in which quantitative and qualitative methods from different disciplines are integrated to comprehensively tackle a complex phenomenon (Yin 2003). Research was conducted during a period of eight years starting in 2005, during which subsequent campaigns of data gathering were designed on the basis of previous achievements in an iterative process aimed at achieving a wide range of evidences on the effects of land abandonment on landscape and biodiversity.

\section{Changes in land cover}

To know in detail the land-cover changes occurring at our study site, three land-cover maps were built from the cadastral cartography. The cadastral cartography was available for the years 2013 (Directorate General for Cadastre, Spanish Ministry of Finances and Public Administrations), 1954 (Town Council of Sant Celoni and Cadastral Regional Authority), and 1856 (Archives of Instituto Geográfico Nacional, ref. D-12-5). The 2013 cartographic base and associated data on land uses were downloaded from the Directorate General for Cadastre Electronic Site (http://www.sedecatastro.gob.es/ovcinicio.aspx) in standard GIS format. Plot polygons were then labeled with their corresponding land use as reported by the associated data. Throughout the text, "plot" refers to the basic administrative unit of the cadastral cartography; a property can be composed of more than one plot. Photo interpretation of orthophotos taken in 2012, provided by the Cartographic Institute of Catalonia at a scale of 1:5000, available at http://www.icc.cat, was used to correct mistakes and to refine the cadastral information where necessary.

The 1954 cadastral maps were scanned and georeferenced in GIS. Plot layout was drawn using the plot layout of 2013 as a basis, which was edited according to the information provided by the scanned maps. Backward reconstruction was chosen because the cadastral plot layout of 2013 is basically the same as that of 1954 , except in the areas parceled for development in the 1960s, where the original layout was redrawn. Plot polygons were then labeled with their corresponding (main) land use as reported by the associated tables, obtained at the Town Council of Sant Celoni. Information gaps and doubts were resolved through photo interpretation of the aerial photographs of 1956, provided by the Cartographic Institute of Catalonia at a scale of 1:30,000.

A photograph of the 1856 map (scale 1:5000) was scanned at a high resolution and georeferenced in GIS. Plot layout was drawn using the plot layout of 1954 as a basis, which was edited and adapted to the information provided by the scanned map. Polygons were then labeled with their corresponding (main) land use as reported by the statistical data of the old Olzinelles municipality from 1853 (Archives of the Crown of Aragon, ref. TER-963). Both the map and the statistics belong to the documentation produced after the Spanish fiscal reform of 1845 (Nadal et al. 2005) and had a common codification of plots. However some mismatches between the plot codes in the map and those in the statistics occurred. They were addressed by correlating both codifications through known plots, i.e., plots that could be undoubtedly identified in both sources because they contained the name of the farmhouse. When the map had more than one plot with the same code, land uses reported by the statistics were assigned to the different plots according to plot size and geographical criteria.

Land use categories from different sources were then grouped and homogenized in a common classification of land covers to allow for intercomparison and analysis of change. The "forest" category included both spontaneous forests and plantations. For the purpose of simplifying the data layout, years are given in round numbers $(1850,1950$, and 2010).

\section{Changes in landscape ecological patterns}

To characterize the changes in landscape ecological patterns, landscape metrics were calculated for the land-cover maps obtained from the cadastral cartography. Selected metrics included two of the most widely used by landscape ecologists when it comes to assessing landscape in terms of land-cover equidiversity and fragmentation (Jaeger 2000, Moser et al. 2007, Parcerisas et al. 2012): Shannon index $(H)$ used to measure landcover diversity (Equation 1); and effective mesh size (MESH), which is the inverse of the extent of fragmentation (Equation 2). These metrics are considered suitable for scales ranging from local (1:500-1:1000) to landscape $(1: 5000-1: 10,000)$ to regional (1:50,000-1:100,000). Urban and unproductive areas, as well as the road network, were excluded from the calculation of landscape metrics. Even if urban sprawl increases land-cover diversity, it might have a negative effect on ecological processes because of habitat loss, the barrier effect, and an increased consumption of resources. The inclusion of artificial land covers would mask the results for agro-silvo-pastoral mosaics, which are our foci.

$$
H=-\sum\left(P_{i} \ln P_{i}\right)
$$

where $P_{i}$ is the proportion of land matrix occupied by each type of cover.

$$
M E S H=\sum\left(A_{i}^{2}\right) 1000 / \Sigma\left(A_{i}\right)
$$

where $A_{i}$ is the area of each polygon. 
The information provided by the landscape metrics was complemented by information on 12 bioindicator species. We mostly relied on studies from the ecological monitoring scheme of the Montnegre-Corredor Natural Park, which monitors selected taxa to inform policy making (Bombí 2004). Some plants, butterflies, birds, and mammals were selected as examples of (1) species with receding populations linked to declining open habitats such as cereal fields, vineyards, pasturelands, and forest clearings, i.e., 8 indicator species; and (2) species with increasing populations linked to expanding dense forests, i.e., 4 indicator species. Importantly, these species were not used as proxy for the overall biodiversity of the area but to check whether the trends detected by landscape metrics were actually perceptible on the ground.

\section{Changes in land uses}

To understand how changing socioeconomic activities shaped the ecological features of the landscape, we collected information on land uses, plot features, and landownership structure. The cadastral sources from the first methodological step were used to create three databases. Each database, i.e., 1850, 1950, and 2010, contained all the plots reported by the corresponding source. The information was introduced at the plot level and included all land uses reported for each plot and their relative area within the plot. Information on dominant land use, plot area, and landowner was also included. Land use categories from different sources were homogenized in a common classification. As for forest categories, some included only spontaneous forests, i.e., holm oak or cork oak (Quercus ilex or Q. suber), whereas others included mostly plantations, i.e., chestnut (Castanea sativa), or pine (Pinus spp.). Basic statistics on plot count, plot size, number of uses per plot, and land-use frequency were calculated to identify the main landuse patterns in 1850, 1950, and 2010. Differences between time slots were analyzed through two-tailed tests assuming equal variances with a significance level of 0.05 . To account for landownership structure and its influence on land-use patterns, the properties in our study area were classified into five categories ( $<1$ ha, 1-5 ha, 5-10 ha, 10-100 ha, and > 100 ha) within which the frequencies of each land-use category were calculated.

\section{Characterization of peasant land management}

To understand how peasant management shaped landscape structure, we conducted semistructured interviews with local peasants. Interviews were carried out with a sample of 12 men and 8 women born between 1913 and 1960 that lived in farmhouses and/or were engaged in rural activities at our study site. We chose interviews because they allowed for an in-depth exploration of the issue under scrutiny and because detailed qualitative information could be collected from relatively few individuals. The interviewees were selected by snowball sampling (Bernard 2006) and balanced in terms of access to land and labor conditions, i.e., small, medium, and large landowners; sharecroppers; and day laborers, as well as of types of work, i.e., agriculture, livestock, and forestry. Interviewees were asked specific questions about management practices of fields, pastures, and forests, including type of crops, end use of yields, felling techniques and rotations, and livestock management. Special emphasis was placed on capturing the relationship between landmanagement practices and landscape structure. The interviews, conducted in Catalan, were recorded and transcribed for content analysis. At the time the interviews were carried out, only two of the informants were active in farming; the others had left their farmhouses and lands several decades before. The informants placed the reported land-management practices in the past, mostly referring to their childhood and youth. Hence the resulting characterization of peasant land management was considered to be roughly representative of the first half of the 20th century.

\section{RESULTS}

\section{Land-cover changes}

In 1850 , forests covered $53 \%$ of the study area, pastureland $26 \%$, vineyard $12 \%$, and rain-fed farmland $6 \%$ (Table 1). Forests and pastures were mostly located in the northern and southern areas. They intermingled with patches of rain-fed farmland and vineyards occurring around farmhouses, which were scattered across the hills and in the valley bottoms (Fig. 3). An area of vineyard specialization occurred in the northwestern area, closer to the town of Sant Celoni. In 1950, forest covered $85 \%$ of the area, pastureland shrunk to $1 \%$, and vineyards decreased to $4 \%$ (Table 1). About $92 \%$ of the pastureland and $60 \%$ of the vineyards existing in 1850 were classified as forest in 1950 (GIS land-cover intersection matrix, not shown in tables). The area of vineyard concentration contracted remarkably. The landscape was clearly dominated by forests, but these were still intermingled with patches of rain-fed arable land and vineyards (Fig. 4). In 2010, forest covered $86 \%$ of the area. All farmland categories together represented $2 \%$ of the study area and only some remnant patches persisted in the valley bottoms. Urban areas reached $4 \%$ of the study area, and the road network covered about 5\% (Table 1, Fig. 5). Although land-cover changes occurring in the period 1850-1950 affected $42 \%$ of the study area, only $19 \%$ of it experienced changes in the period 1950-2010. Urban areas and road network in 2010 occurred at the expense of woodland conversion (64\%) and farmland conversion (23\%; GIS land-cover intersection matrix, not shown in tables).

Table 1. Land-cover distribution in 1850, 1950, and 2010.

\begin{tabular}{|c|c|c|c|c|c|c|}
\hline \multirow[t]{2}{*}{ Land cover } & \multicolumn{2}{|c|}{1850} & \multicolumn{2}{|c|}{1950} & \multicolumn{2}{|c|}{2010} \\
\hline & ha & $\%$ & ha & $\%$ & ha & $\%$ \\
\hline Forest & 1200.9 & 52.6 & 1950.2 & 85.4 & 1962.2 & 85.9 \\
\hline Irrigated farmland & 10.6 & 0.5 & 55.4 & 2.4 & 18.6 & 0.8 \\
\hline Rain-fed farmland & 141.9 & 6.2 & 126.6 & 5.5 & 26.6 & 1.2 \\
\hline Riverside & 35.5 & 1.6 & 4.2 & 0.2 & 16.2 & 0.7 \\
\hline Pastureland & 602.8 & 26.4 & 25.7 & 1.1 & 28.8 & 1.3 \\
\hline Urban area & 1.5 & 0.1 & 1.9 & 0.1 & 93.5 & 4.1 \\
\hline Vineyard & 275.1 & 12.0 & 96.5 & 4.2 & 1.4 & 0.1 \\
\hline $\begin{array}{l}\text { Hydrographical } \\
\text { network }\end{array}$ & 5.0 & 0.2 & 5.1 & 0.2 & 4.7 & 0.2 \\
\hline Road network & 11.5 & 0.5 & 18.9 & 0.8 & 105.9 & 4.6 \\
\hline Unproductive & 0.0 & 0.0 & 0.0 & 0.0 & 25.4 & 1.1 \\
\hline Total & 2284.7 & 100.0 & 2284.7 & 100.0 & 2283.2 & 100.0 \\
\hline
\end{tabular}

\section{Changes in landscape ecological patterns}

The above-mentioned land-cover changes had a deep impact on the landscape ecological patterns as measured by the selected metrics. The effective mesh size recorded an upward trend meaning less landscape heterogeneity over time, and the Shannon index showed a remarkable landscape equi-diversity decrease (Table 2). Table 3 lists the selected bioindicator species, the survey methods used by the corresponding authors, and their conservation status. As for the examples of declining species from 
Fig. 3. Land-cover map of Olzinelles (1850).

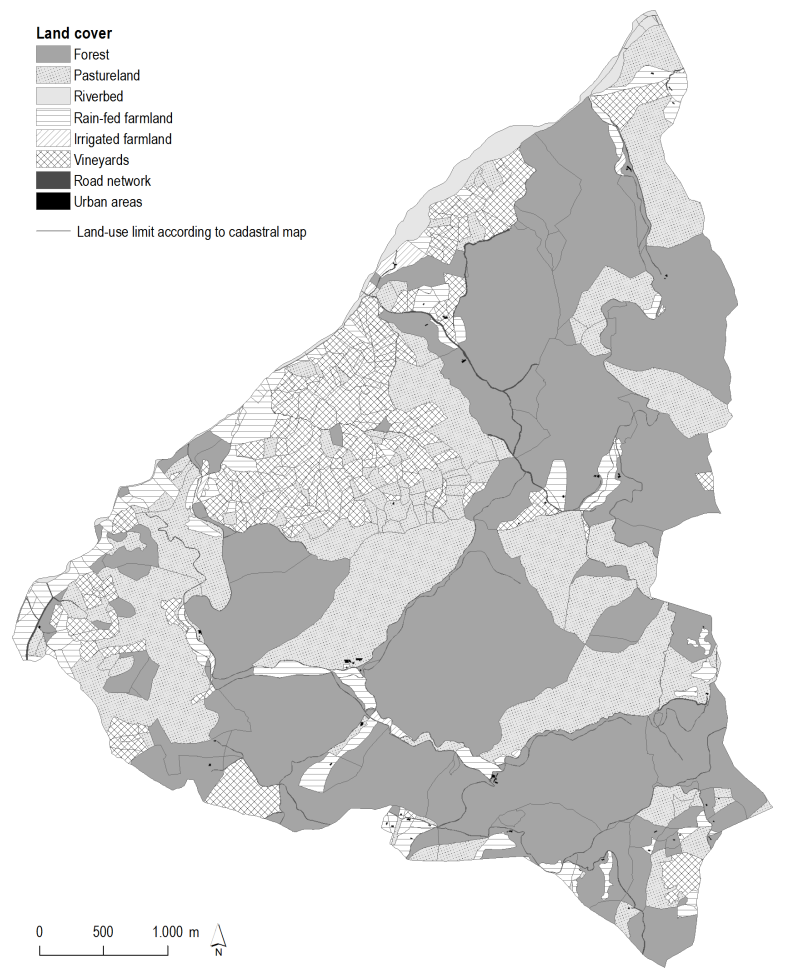

Fig. 4. Land-cover map of Olzinelles (1950).

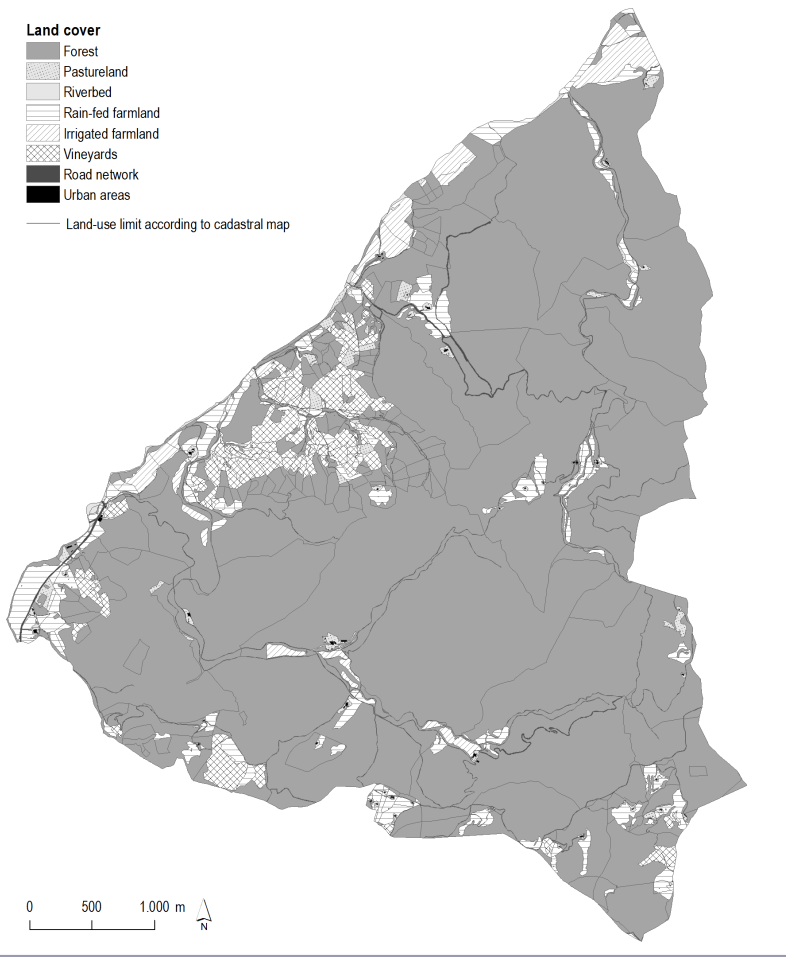

Fig. 5. Land-cover map of Olzinelles (2010).

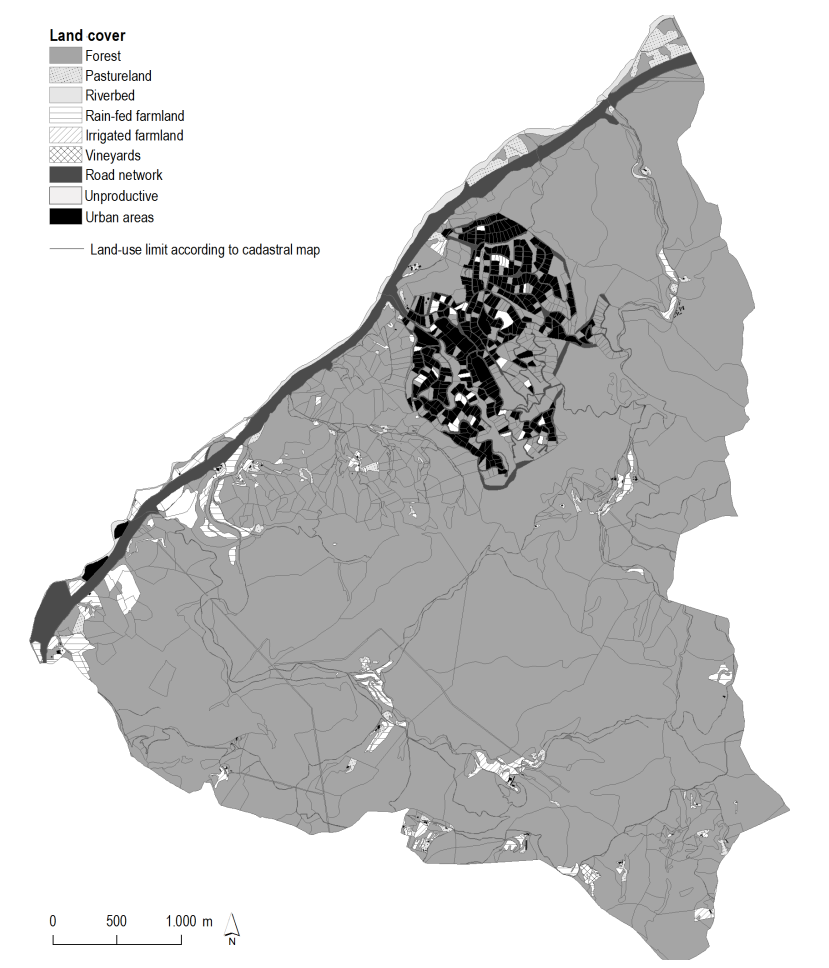

open habitats, plants included rare species strongly related to forest clearings for charcoal production (Geranium lanuginosum and Stachys alpina), and species from rocky grounds (Isoetes duriaei). They were reported to be under threat because of the disappearance of charcoal making and/or habitat afforestation. In particular, G. lanuginosum was considered locally extinct. Butterflies included species that experienced sharp population declines caused by the conversion of grasslands to pine plantations. Birds included the Red-legged Partridge (Alectoris rufa), a nesting species highly dependent on farmland habitats, which showed a clear recessive trend. Regarding the examples of expanding species from forest habitats, two butterfly species were reported to experience strong increments with afforestation, and one bird species particularly related to pine plantations, Bonelli's Warbler, Phylloscopus bonelli, was reported to experience a strong increase. The wild boar (Sus scrofa) was reported to expand in population because of increasing forest cover and the abandonment of grazing and charcoal production.

Table 2. Effective mesh size and Shannon index for 1850, 1950, and 2010.

\begin{tabular}{lccc}
\hline \hline Landscape Metrics & \multicolumn{3}{c}{ Year } \\
\cline { 2 - 4 } & 1850 & 1950 & 2010 \\
\hline Effective mesh size $\left(\right.$ MESH $\left.; \mathrm{km}^{2}\right)$ & 0.99 & 2.01 & 2.13 \\
Shannon index $(H)$ & 1.74 & 0.83 & 0.35 \\
\hline
\end{tabular}


Table 3. List of selected bioindicator species. Population dynamics were (1) negatively affected by the regression of open habitats, and (2) positively affected by the expansion of forests and tree plantations.

\begin{tabular}{|c|c|c|c|}
\hline \multirow[t]{2}{*}{ Group } & \multirow[t]{2}{*}{ Species } & \multicolumn{2}{|c|}{ Conservation status } \\
\hline & & $\mathrm{IUCN}^{\dagger \dagger}$ & Catalonia $^{\text {犃 }}$ \\
\hline \multicolumn{4}{|c|}{ (1) Declining species from fields, grasslands, and forest clearings } \\
\hline \multirow[t]{3}{*}{ Plants $^{\dagger}$} & Geranium lanuginosum & n.a. & $\mathrm{VU} / \mathrm{CR}$ \\
\hline & Stachys alpina & n.a. & LC \\
\hline & Isoetes duriaei & n.a. & LC/VU \\
\hline \multirow[t]{4}{*}{ Butterflies $^{*}$} & Maniola jurtina & n.a. & n.a. \\
\hline & Polyommatus icarus & n.a. & n.a. \\
\hline & Lycaena phlaeas & n.a. & n.a. \\
\hline & Colias crocea & n.a. & n.a. \\
\hline Birds $^{\S}$ & Alectoris rufa & $\mathrm{LC}$ & $\mathrm{LC}$ \\
\hline \multicolumn{4}{|c|}{ (2) Expanding species from forests and tree plantations } \\
\hline \multirow[t]{2}{*}{ Butterflies } & Libythea celtis & n.a. & n.a. \\
\hline & Nymphalis antiopa & n.a. & n.a. \\
\hline Birds $\pi^{\pi}$ & Phylloscopus bonelli & $\mathrm{LC}$ & $\mathrm{LC}$ \\
\hline Mammals $^{\#}$ & Sus scrofa & $\mathrm{LC}$ & n.a. \\
\hline
\end{tabular}

Gutiérrez (2001). Review of the classical flora by Montserrat (1989, c1955-1964); selection of taxa according to conservationist criteria; in situ verification of classical locations for selected taxa; and identification of main threats for each of them. Species reported in the table refer to the Montnegre Mountains.

"Miralles and Stefanescu (2004). One transect was walked in Can Riera de Vilardell (see Fig. 1) as part of the Catalan Butterfly Monitoring Scheme, which uses a standardized methodology based on weekly counts between March and September along a fixed route. The transect was $2300 \mathrm{~m}$ long and went through different habitat types, including grasslands transformed to pine plantations. Data were available for the period 1994-2005. Species reported in the table were classified as grassland species based on an index that relates species to habitat features, using data from $\sim 130$ transects in Catalonia (S. Herrando, L. Brotons, M. Anton, F. Páramo, D. Villero, N. Titeux, J. Quesada, and C. Stefanescu, unpublished manuscript).

${ }^{\S}$ Ribas and Pons (2001). Different standard methods, such as total censuses, parcel censuses, and punctual indexes of abundance were used. The original results concerned the Montnegre-Corredor Mountains. In the table, we only included species present in our study area.

'Miralles and Stefanescu (2004). See note ${ }^{\ddagger}$ for methods and data. Species reported in the table were classified as forest species based on an index that relates each species to habitat features, using data from $\sim 130$ transects in Catalonia (S. Herrando, L. Brotons, M. Anton, F. Páramo, D. Villero, N. Titeux, J. Quesada, and C. Stefanescu, unpublished manuscript).

"Anton et al. (2013). Four transects, $3000 \mathrm{~m}$ long each, were walked in the Montnegre-Corredor Mountains as part of the Catalan Common Bird Monitoring Scheme, which uses a standardized methodology based on four censuses (two in springtime and two in wintertime) per transect. Transects went through different habitat types. Data were available for the period 2002-2013 (some gaps existed). Abundance indexes were calculated using log-lineal models and Poisson distributions. The species reported in the table was classified as a forest species, based on an index that relates species to habitat features. The original results concerned the Montnegre-Corredor Mountains. In the table, we only included species present in our study area. ${ }^{\#}$ Rosell and Navàs (2014). Wild boar density was estimated based on the number of hunted animals, hunting effort, and hunting area as part of a monitoring program that gathers data in 17 areas of Catalonia during hunting seasons (September-February). Data were available for the period 2001-2014. The benefits of forest expansion for the species were assessed by Rosell (1998).

${ }^{\dagger \dagger}$ The IUCN Red List of Threatened Species (IUCN 2014); n.a.: not assessed; LC: Least Concern.

Plants: IUCN criteria (1994 version) adapted to Catalonia by Gutiérrez (2004) and Sáez and Soriano (2000); birds: IUCN criteria adapted to Catalonia by the Catalan Ornithological Institute (http://www.sioc.cat); n. a.: not assessed; LC: Least Concern; VU: Vulnerable; CR: Critically Endangered.

\section{Changes in land use, plot features, and landownership structure} Table 4 summarizes the basic plot data considering all the plots reported by the sources, i.e., farmland, pastureland, forest, and urban areas. In 2010, the plot count more than doubled that of 1950, and mean plot size (2.09 ha) was significantly lower than that of 1950 (4.81 ha) and 1850 (6.88 ha). The mean number of uses per plot in each time slot was significantly different, showing a decreasing trend over the analyzed period. In 1850 , about $41 \%$ of the plots reported four or more uses and about $24 \%$ reported three uses. In 1950, about one third of the plots had only one use, but still $28 \%$ had four or more uses. Instead in 2010 , about $83 \%$ of the plots were reported to have only one use. Plot-land uses also showed important changes (Table 5). In 1850, more than half of the plots had vineyards as the main land use, about $20 \%$ had pastures, and 16\% had rain-fed farmland. Except for holm oak forest, forest-land uses reached only marginal values. In 1950, the proportion of plots devoted to vineyards $(16 \%)$ and pastures (about $4 \%$ ) were significantly lower than in 1850 , and rain-fed farmland reached a similar value $(14.5 \%)$. The majority of plots had forests as main land use and most forest uses reached significantly higher values than in 1850 . In particular, Cork Oak forest was the main land use in $28.3 \%$ of the plots, followed by holm oak forest $(13.8 \%)$, and riverside and pine forests $(8.5 \%$ of the plot count each). In 2010, plots devoted to agriculture and pastures together represented less than $5 \%$ of the total plot count and had significantly lower values than in 1950. As in 1950, most of the plots were devoted to forest uses. Holm oak forest $(29.9 \%)$ and pine forest (19.1\%) were significantly higher than in 1950 , whereas cork oak forest $(5.6 \%)$ and riverside forest $(3.1 \%)$ were significantly lower. About one third of the plots were reported as urban.

Table 4. Basic plot data (count, size, and number of land uses) and plot distribution according to the number of reported land uses for years 1850, 1950, and 2010.

\begin{tabular}{|c|c|c|c|c|c|}
\hline & \multicolumn{5}{|c|}{ Year } \\
\hline & \multicolumn{2}{|c|}{$1850(\mathrm{~A})$} & \multicolumn{2}{|c|}{$1950(\mathrm{~B})$} & $2010(\mathrm{C})$ \\
\hline Total area (ha) & 2215.03 & & 2258.55 & & 2196.18 \\
\hline Plot count & 322 & & 470 & & 1050 \\
\hline Mean plot size (ha) & 6.88 & $\mathrm{C}$ & 4.81 & $\mathrm{C}$ & 2.09 \\
\hline Variance & 962.19 & & 242.73 & & 80.64 \\
\hline Median plot size (ha) & 1.19 & & 0.80 & & 0.26 \\
\hline Mean no. uses per plot & 4.45 & $\mathrm{BC}$ & 3.34 & $\mathrm{C}$ & 1.65 \\
\hline Median no. uses per plot & 3.00 & & 2.00 & & 1.00 \\
\hline \multicolumn{6}{|l|}{ No. uses per plot: } \\
\hline 1 & $12.11 \%$ & & $33.62 \%$ & A & $83.05 \% \quad \mathrm{AB}$ \\
\hline 2 & $22.98 \%$ & $\mathrm{C}$ & $21.70 \%$ & $\mathrm{C}$ & $6.38 \%$ \\
\hline 3 & $23.91 \%$ & $\mathrm{BC}$ & $16.81 \%$ & $\mathrm{C}$ & $3.05 \%$ \\
\hline$\geq 4$ & $40.99 \%$ & $\mathrm{BC}$ & $27.87 \%$ & $\mathrm{C}$ & $7.52 \%$ \\
\hline
\end{tabular}

Note: The results are based on the two-tailed t-test (for mean values) and the two-tailed $\mathrm{Z}$-test (for percentages) assuming equal variances with a significance level of 0.05 . For each significant pair, the key of the category $(\mathrm{A}, \mathrm{B}, \mathrm{C})$ shows up in the category with the largest average value. Using the Bonferroni correction, tests have been adjusted for all pair-wise comparisons. 
Table 5. Plot count and percentage according to main land use for years 1850, 1950, and 2010.

\begin{tabular}{|c|c|c|c|c|c|c|c|c|c|}
\hline \multirow{4}{*}{$\begin{array}{l}\text { Land use } \\
\text { Holm Oak forest }\end{array}$} & \multicolumn{9}{|c|}{ Year } \\
\hline & \multicolumn{3}{|c|}{1850} & \multicolumn{3}{|c|}{1950} & \multicolumn{3}{|c|}{2010} \\
\hline & \multirow{2}{*}{$\frac{\text { Count }}{26}$} & \multicolumn{2}{|c|}{$\%(\mathrm{~A})$} & \multirow{2}{*}{$\frac{\text { Count }}{65}$} & \multicolumn{2}{|c|}{$\%(\mathrm{~B})$} & \multirow{2}{*}{$\begin{array}{c}\text { Count } \\
314\end{array}$} & \multicolumn{2}{|c|}{$\%(\mathrm{C})$} \\
\hline & & $8.1 \%$ & & & $13.8 \%$ & A & & $29.9 \%$ & $\mathrm{AB}$ \\
\hline Chestnut forest & 2 & $0.6 \%$ & & 8 & $1.7 \%$ & $\mathrm{C}$ & 3 & $0.3 \%$ & \\
\hline Riverside forest & 1 & $0.3 \%$ & & 40 & $8.5 \%$ & $\mathrm{AC}$ & 33 & $3.1 \%$ & A \\
\hline Pine forest & 3 & $0.9 \%$ & & 40 & $8.5 \%$ & $\mathrm{~A}$ & 201 & $19.1 \%$ & $\mathrm{AB}$ \\
\hline Cork Oak forest & 3 & $0.9 \%$ & & 133 & $28.3 \%$ & $\mathrm{AC}$ & 59 & $5.6 \%$ & A \\
\hline Irrigated farmland & 0 & $0.0 \%$ & (a) & 21 & $4.5 \%$ & $\mathrm{C}$ & 16 & $1.5 \%$ & \\
\hline Rain-fed farmland & 52 & $16.1 \%$ & $\mathrm{C}$ & 68 & $14.5 \%$ & $\mathrm{C}$ & 11 & $1.0 \%$ & \\
\hline Vineyard & 168 & $52.2 \%$ & $\mathrm{BC}$ & 75 & $16.0 \%$ & $\mathrm{C}$ & 2 & $0.2 \%$ & \\
\hline Pastureland & 66 & $20.5 \%$ & $\mathrm{BC}$ & 18 & $3.8 \%$ & $\mathrm{C}$ & 15 & $1.4 \%$ & \\
\hline Urban area & 0 & $0.0 \%$ & (a) & 2 & $0.4 \%$ & & 354 & $33.7 \%$ & B \\
\hline Unproductive & 0 & $0.0 \%$ & (a) & 0 & $0.0 \%$ & (a) & 42 & $4.0 \%$ & \\
\hline No data & 1 & $0.3 \%$ & & 0 & $0.0 \%$ & (a) & 0 & $0.0 \%$ & (a) \\
\hline Total & 322 & $100.0 \%$ & & 470 & $100.0 \%$ & & 1050 & $100.0 \%$ & \\
\hline
\end{tabular}

Note 1: The results are based on the two-tailed Z-test assuming equal variances with a significance level of 0.05 . For each significant pair, the key of the category (A, B, C) shows up in the category with the largest average value. Using the Bonferroni correction, tests have been adjusted for all pairwise comparisons. (a): No observations were found in that particular category.

Note 2: The main land use is the one with the largest relative area within each plot.

Table 6 presents the results for landownership structure. In 1850, eight landowners had properties of more than 100 ha, whereas most of the people registered in the cadastre had access to properties of less than 5 ha. Landownership structure was similar in 1950, even if medium-to-large landowners, with properties between 10 and 100 ha, represented a higher percentage than in 1850. The situation in 2010 was considerably different because the proportion of smallholders, with properties of less than 1 ha, increased to $83 \%$. Landownership categories had diverse land-use distributions (Table 7). In 1850, the largest estates were mainly devoted to forestry and pastures, whereas the smallest properties were mostly farmland with vineyards being the main land use of small peasants. In 1950, the smallest properties still devoted an important proportion of land to agricultural uses, but forestry gained importance. In 2010, the properties of less than 1 ha were no longer devoted to agriculture; instead, almost half of their area was reported to have urban uses (Table 7).

\section{Peasant land management}

We provide a summary of peasant land-management practices as reported by our informants, but for a complete account linking management practices to particular habitats and species, see Appendix 1 and 2. The role of such practices in shaping landscape patterns will be discussed in the next section. Peasants in Olzinelles located their farmhouses near small streams. The streams were terraced to create dry farming land, orchards, and gardens. Stone walls were used to maintain terraces, and trees, shrubs, and vines were kept in field edges (Interviewees 7, 18). Rain-fed farmland was mostly devoted to the production of wheat for self-supply. The land was ploughed, fertilized, and sowed by December. It was later hoed when necessary. In June and July the wheat was harvested and threshed, then the grain was collected and brought to the mill to produce flour and bran (Interviewees 1, 3, 17). Other crops such as oats, barley, lucerne, and sorghum were grown mostly to feed stabled livestock. Vines were cultivated on sunny slopes without terracing. They were laid out along zigzag ditches, which collected water runoff in purpose-built pools. Vineyards were ploughed once a year and hoed several times to weed. The harvest was done in September and October, when grapes were trodden and pressed to produce different kinds of wine intended both for self-supply and as cash product (Interviewees 1, 3, 4, 17). Secondary crops in vineyards included olive trees, fig trees, cherry trees, aromatic plants, and fodders. Olive trees, which could also occur in specific groves, were harvested in November and December. The olives were crushed in the oil mill to produce oil, which was mostly used for self-supply and, to a lesser extent, as cash product (Interviewees 1, 3, 17).

Table 6. Count and percentage of landowners according to property size for years 1850,1950 , and 2010.

\begin{tabular}{|c|c|c|c|c|c|c|}
\hline \multirow{3}{*}{$\begin{array}{l}\text { Property } \\
\text { size }\end{array}$} & \multicolumn{6}{|c|}{ Year } \\
\hline & \multicolumn{2}{|c|}{1850} & \multicolumn{2}{|c|}{1950} & \multicolumn{2}{|c|}{2010} \\
\hline & Count & $\%$ & Count & $\%$ & Count & $\%$ \\
\hline$<1$ ha & 70 & $28.9 \%$ & 66 & $34.6 \%$ & 634 & $83.0 \%$ \\
\hline $1-5$ ha & 141 & $58.3 \%$ & 91 & $47.6 \%$ & 99 & $13.0 \%$ \\
\hline $5-10$ ha & 9 & $3.7 \%$ & 4 & $2.1 \%$ & 9 & $1.2 \%$ \\
\hline $10-100$ ha & 14 & $5.8 \%$ & 25 & $13.1 \%$ & 17 & $2.2 \%$ \\
\hline$>100$ ha & 8 & $3.3 \%$ & 5 & $2.6 \%$ & 5 & $0.7 \%$ \\
\hline Total & 242 & $100.0 \%$ & 191 & $100.0 \%$ & 764 & $100.0 \%$ \\
\hline
\end{tabular}

Farmland patches around farmhouses were surrounded by forests of varying composition and structure, which were intensively managed by the largest landowners to produce a wide array of cash products. Holm oak forests were coppiced every 7 to 10 years for firewood. Holm oaks reaching the diameter required by the market were selected, together with dead, dried up, or bent ones. Straight and healthy oaks were left standing for the next harvest, which was done after 7 to 10 years. The third selection was 
Table 7. Relative area of land uses according to property size for years 1850, 1950, and 2010.

\begin{tabular}{|c|c|c|c|c|c|c|}
\hline \multirow[t]{2}{*}{ Year } & \multirow[t]{2}{*}{ Land use } & \multicolumn{5}{|c|}{ Property size } \\
\hline & & $<1$ ha & $1-5$ ha & 5-10 ha & 10-100 ha & $>100$ ha \\
\hline \multirow[t]{12}{*}{1850} & Holm oak forest & $2.9 \%$ & $5.0 \%$ & $14.9 \%$ & $46.3 \%$ & $40.7 \%$ \\
\hline & Chestnut forest & $0.5 \%$ & $0.6 \%$ & $1.7 \%$ & $1.6 \%$ & $0.2 \%$ \\
\hline & Riverside forest & $0.3 \%$ & $0.4 \%$ & $0.0 \%$ & $0.6 \%$ & $0.4 \%$ \\
\hline & Pine forest & $0.0 \%$ & $0.1 \%$ & $0.0 \%$ & $2.9 \%$ & $5.7 \%$ \\
\hline & Cork oak forest & $1.7 \%$ & $1.3 \%$ & $2.7 \%$ & $11.3 \%$ & $10.1 \%$ \\
\hline & Irrigated farmland & $0.0 \%$ & $0.0 \%$ & $0.0 \%$ & $0.5 \%$ & $0.3 \%$ \\
\hline & Rain-fed farmland & $11.3 \%$ & $16.6 \%$ & $9.6 \%$ & $10.6 \%$ & $2.8 \%$ \\
\hline & Vineyard & $68.1 \%$ & $52.8 \%$ & $39.4 \%$ & $4.4 \%$ & $3.3 \%$ \\
\hline & Pastureland & $15.0 \%$ & $23.0 \%$ & $17.2 \%$ & $21.6 \%$ & $36.4 \%$ \\
\hline & Urban area & $0.2 \%$ & $0.2 \%$ & $0.1 \%$ & $0.1 \%$ & $0.0 \%$ \\
\hline & Unproductive & $0.0 \%$ & $0.0 \%$ & $0.0 \%$ & $0.0 \%$ & $0.0 \%$ \\
\hline & No data & $0.0 \%$ & $0.0 \%$ & $14.4 \%$ & $0.0 \%$ & $0.0 \%$ \\
\hline \multirow[t]{12}{*}{1950} & Holm oak forest & $9.2 \%$ & $15.2 \%$ & $5.8 \%$ & $30.1 \%$ & $33.4 \%$ \\
\hline & Chestnut forest & $0.9 \%$ & $3.9 \%$ & $0.4 \%$ & $1.3 \%$ & $0.0 \%$ \\
\hline & Riverside forest & $4.9 \%$ & $3.3 \%$ & $1.5 \%$ & $1.2 \%$ & $1.7 \%$ \\
\hline & Pine forest & $20.0 \%$ & $12.9 \%$ & $9.0 \%$ & $8.1 \%$ & $9.5 \%$ \\
\hline & Cork oak forest & $12.6 \%$ & $15.3 \%$ & $26.3 \%$ & $49.2 \%$ & $47.6 \%$ \\
\hline & Irrigated farmland & $0.2 \%$ & $3.1 \%$ & $0.4 \%$ & $3.0 \%$ & $2.5 \%$ \\
\hline & Rain-fed farmland & $19.1 \%$ & $13.2 \%$ & $21.2 \%$ & $5.3 \%$ & $3.7 \%$ \\
\hline & Vineyard & $27.5 \%$ & $29.8 \%$ & $26.5 \%$ & $1.1 \%$ & $1.0 \%$ \\
\hline & Pastureland & $5.0 \%$ & $3.2 \%$ & $8.6 \%$ & $0.7 \%$ & $0.6 \%$ \\
\hline & Urban area & $0.7 \%$ & $0.1 \%$ & $0.3 \%$ & $0.1 \%$ & $0.1 \%$ \\
\hline & Unproductive & $0.0 \%$ & $0.0 \%$ & $0.0 \%$ & $0.0 \%$ & $0.0 \%$ \\
\hline & No data & $0.0 \%$ & $0.0 \%$ & $0.0 \%$ & $0.0 \%$ & $0.0 \%$ \\
\hline \multirow[t]{12}{*}{2010} & Holm oak forest & $28.0 \%$ & $35.3 \%$ & $55.2 \%$ & $31.6 \%$ & $74.0 \%$ \\
\hline & Chestnut forest & $0.0 \%$ & $0.4 \%$ & $0.0 \%$ & $3.1 \%$ & $0.0 \%$ \\
\hline & Riverside forest & $1.3 \%$ & $3.1 \%$ & $0.7 \%$ & $2.6 \%$ & $3.1 \%$ \\
\hline & Pine forest & $15.2 \%$ & $36.5 \%$ & $35.2 \%$ & $15.7 \%$ & $9.0 \%$ \\
\hline & Cork oak forest & $1.0 \%$ & $7.0 \%$ & $6.4 \%$ & $40.3 \%$ & $11.8 \%$ \\
\hline & Irrigated farmland & $0.8 \%$ & $2.6 \%$ & $0.0 \%$ & $1.0 \%$ & $0.5 \%$ \\
\hline & Rain-fed farmland & $0.1 \%$ & $2.5 \%$ & $0.0 \%$ & $2.2 \%$ & $0.7 \%$ \\
\hline & Vineyard & $0.2 \%$ & $0.6 \%$ & $0.0 \%$ & $0.0 \%$ & $0.0 \%$ \\
\hline & Pastureland & $0.4 \%$ & $4.0 \%$ & $1.5 \%$ & $2.5 \%$ & $0.5 \%$ \\
\hline & Urban area & $48.3 \%$ & $4.1 \%$ & $0.0 \%$ & $0.1 \%$ & $0.0 \%$ \\
\hline & Unproductive & $4.7 \%$ & $3.9 \%$ & $0.9 \%$ & $0.7 \%$ & $0.4 \%$ \\
\hline & No data & $0.0 \%$ & $0.0 \%$ & $0.0 \%$ & $0.0 \%$ & $0.0 \%$ \\
\hline
\end{tabular}

performed 7 to 10 years after the second one. After an additional 7 to 10 years the cycle restarted, selecting the oaks that had been felled 21 to 30 years before (Interviewee 1). Because holm oaks quickly sprouted after felling, a precise sprout selection was required to prepare the trees for the harvest. An initial selection was performed about five to six years after the felling, when four sprouts per stump were left standing. Several years later, an additional sprout selection left only two sprouts per stump. In the most remote forests, entailing higher transportation costs, charcoal was produced to reduce firewood weight while maintaining its calorific content (Interviewees 2, 6). The coppice selection system and the production of charcoal were very similar for cork oak forests, though they were adapted to the production of cork. For this, trees were debarked in June and July every 14 to 17 years. Both in holm and cork oak forests, competitor tree species were felled and brush was periodically slashed (Interviewees 1, 2, 4, 5, 6). Brushwood was sold as thin firewood or used to produce fine charcoal (Interviewees 1, 3). The stumps of some bush species were uprooted and sold to manufacturers of pipes and other wooden products (Interviewees 1, 2, 5, 6).
Sheep and goat flocks and pig herds grazed in holm and cork oak forests, as well as on scrublands and pasturelands. Herds of up to 200 pigs grazed acorns during the winter. In springtime they were fed in the farmhouse and then brought to the slaughterhouse to be sold as meat (Interviewee 11). Flocks of sheep and goats, composed of 200 to 400 heads, grazed herbs, stems, shrubs, shoots, lower branches of trees, and acorns (Interviewees 4, 11). Some flocks moved in from nearby coastal mountains according to grass availability (Interviewee 9). Other flocks came from the Pyrenees in November and grazed until springtime, when they left to feed on the high pastures after the melting of the snow (Interviewee 11).

\section{DISCUSSION}

The construction of three historical land-cover maps from the cadastral cartography allowed us to know in detail the land-cover changes occurring at our study site during the last 160 years. These mostly consisted of the encroachment of forest on former farmland and pastureland and a considerable expansion of urban areas and the road network (Table 1, Fig. 3, 4, 5). When 
considering the demographic evolution since the mid-19th century (Fig. 2), it becomes apparent that the aforementioned land-cover changes occurred along with (1) rural exodus and the ensuing land abandonment by a peasant population increasingly attracted by nonfarming opportunities in nearby towns (Otero et al. 2013), and (2) the development of single houses for urban dwellers in depreciated forests as part of a broader process of (sub)urbanization of the countryside (Piqueras 2009). The former conformed to the "economic modernization pathway" to forest transition, whereby economic development drives the labor force from agriculture to industry and from rural to urban areas, thereby inducing the conversion of abandoned fields into forests (Rudel et al. 2005, Lambin and Meyfroidt 2010). Secondary forests in our study area included cork oak and holm oak forests resulting from spontaneous regeneration in abandoned farmland and pastureland, plantations of plane trees (Platanus sp.) in former fields along the riverside, and plantations of several pine species in abandoned farmland and vineyards (Table 5; Otero et al. 2011).

Cadastral data on land uses, plot features, and landownership structure shed light on how (changing) socioeconomic activities shaped land-cover distribution and landscape ecological patterns along the forest transition. The uneven pattern of land distribution found in 1850 (Table 6) was the result of a long process of land accumulation underway since the 14th century, when survivors of the Black Death started expanding their farms with the inclusion of other properties that remained abandoned after the plague killed their holders (Otero and Boada 2012). After the Catalan peasant revolt of the 15 th century, those farms gradually accumulated most of the land and entered the 19th century with large expanses of farmland, pastures, and forests under control (Table 7). Population grew, and a greater number of landless people looked for an opportunity to make a living (Fig. 2). The Dutch trade linked the Catalan coast with the fate of the emerging Atlantic economy by purchasing an increasing amount of Catalan liquors. This brought about the expansion of vineyards, which became the most important agricultural change throughout the Catalan industrialization (Badia-Miró and Tello 2014). The relationship between land uses and landownership structure found in our study area (Table 7) makes apparent that vineyard planting opened a gateway for many landless people. They planted vines after forest clearance in plots leased by the largest landowners and combined vine growing with subsistence rain-fed farming (Table 7). However, vineyard specialization in our study area had only limited possibilities because its mountainous relief implied that little arable land was available. Instead, most of the productive lands were devoted to forests and pastures, which had a central role in the economic activities of the largest estates (Table 7). These sold firewood, charcoal, timber, and cork, which were then traded by ship to Barcelona and other coastal cities (Urteaga and Nadal 2013). The small wine-producing peasantry provided most of the workforce required by the large forest estates and engaged as day laborers in tasks such as felling trees and shrubs, producing charcoal, or debarking cork (Otero et al. 2013).

A multiple land-use strategy within particular topographic conditions and an uneven landownership structure resulted in a rather heterogeneous and equi-diverse landscape in 1850 (Table 2, Fig. 3). Later, the Phylloxera plague arrived at the Catalan coast by the end of the century, killed local vines, and put a sudden end to the export-led farmland expansion. Many vineyards were abandoned and afforested, marking the turning point of the forest transition. A dramatic decrease in the population occurred from the 1920s (Fig. 2), when many peasants left Olzinelles and moved to the town of Sant Celoni attracted by an incipient industry (Otero et al. 2013). This led to subsequent afforestation processes (Fig. 4), a significant decrease of land-use diversity within plots (Table 4), and a remarkable loss of landscape heterogeneity and equi-diversity (Table 2). Consequently, land-use mosaics underwent a considerable simplification entailing a reduction of ecotones, i.e., areas of contact between different landscape units featuring important ecological functions (Benton et al. 2003, Hole et al. 2005).

However, the multiple land-use strategy was somehow still in place in the first half of the 20th century. Qualitative interviews allowed us to sketch the particular land-management strategy performed by the local peasant community and to understand how it shaped landscape ecological patterns (see Appendix 1 and 2). Landmanagement practices reported by our informants can be considered to enhance landscape heterogeneity at four spatial scales (Benton et al. 2003). First, heterogeneity within fields or plots could be favored by practices such as mixed uses, for instance by planting olive trees and other fruit trees as secondary crops in vineyards and cereal fields. Importantly, mixed uses were not limited to agriculture but included intermingled agro-forestry and silvo-pastoral systems. For instance, sparse cork oak woods could be ploughed to grow sorghum, beetroot, and fodders (Pagès et al. 2005), young plantations of plane trees were used to cultivate vegetables (Interviewees 5, 6), and forests and scrublands used for firewood were also grazed by pigs, sheep, and goats. Second, heterogeneity between fields was enhanced not only by crop diversity, but also by the presence of field edges, which could be cropped, e.g., fruit trees and vines, or noncropped, e.g., weeds and shrubs. Third, heterogeneity within the largest estates was particularly related to forestry because diverse forest types were favored and because holm and cork oak forests were subdivided in different stands to be coppiced in a rotational sequence (Interviewee 1). The latter strategy provided varying conditions of canopy cover, light availability, tree density, and shrub cover across the estate (Otero et al. 2013). In the riversides, chestnut groves, and pine groves, heterogeneity was enhanced by pruning, sprout selection techniques, and rotations that varied according to forest types and production goals. And fourth, heterogeneity at these three spatial scales aggregated at the landscape level in the whole study area by the simultaneous operation of the different peasant management practices.

The heterogeneity enhanced by peasant land management added to the heterogeneity provided by topography, edaphic factors, and seasonality. Overall, habitat heterogeneity provided resources for a diversity of species (Benton et al. 2003). Even if a complete record of the biodiversity hosted by agro-silvo-pastoral mosaics does not exist in our study area, the oral information gathered through our interviews and some available historical records hint at the ecological communities present therein (Appendix 1 and 2). Cereal fields and margins were foraging and nesting sites for granivorous birds, which fed on both cultivated cereals and spontaneous grasses (Interviewee 3); stone walls and edges were refuges and feeding areas for reptiles; vineyards had abundant populations of partridges (Interviewee 3 ), lizards, and snakes; and 
forests provided habitat for wild boars, which were reported to be numerous already back in the 1920s (Portals 1998).

During the second half of the 20th century, forest cover did not increase substantially (Table 1), but the collapse of charcoal production and firewood felling with the spread of fossil fuels led to a remarkable densification (Otero et al. 2008). Multiple landuse mosaics vanished into an extensive homogeneous forest matrix only punctuated by single housing plots and a highway (Fig. 5, Table 4). Different species reacted differently to land use and land-cover changes as shown by surveys conducted from the 1990s (Table 3). Rare plants found in forest clearings, grassland butterflies, and farmland birds showed recessive trends. Butterflies benefiting from forest vegetation structure, birds particularly related to pine plantations, and a mammal species benefiting from extensive forest cover showed increasing trends. The dynamics of biodiversity assemblages in our study area were not only explained by quantitative changes in habitat size; habitat quality was shown to play a role too. For instance, wild boar populations showed an increasing trend with yearly oscillations caused by changing forest productivity and food availability (Rosell and Navàs 2014); and predatory birds were shown to be particularly sensitive to the disruption of nesting areas by thinning and by the works related to the maintenance of forest tracks (Macià et al. 2013).

The conservation value of each group of species is decided by stakeholders and policy makers according to criteria such as vulnerability, rarity, or cultural values. The Natural Park of Montnegre-Corredor, to which most of our study area belongs, targeted the remaining open habitats as a priority conservation area because they feature high species richness and cover only $3 \%$ of the total protected area (Bombí 2004). However, the attempts to recover grasslands so far have had only limited success because the isolation of grassland animal populations greatly hampers the recolonization of the recovered grasslands (Marull et al. 2015). As reported in other cases, the costs of farmland abandonment in our study area seem to be higher than the benefits brought about by forest expansion (Farina 1997, Preiss et al. 1997, Franco and Sutherland 2004, Laiolo et al. 2004, Moreira and Russo 2007). Our results highlight the loss of land-cover heterogeneity and equi-diversity within the land matrix composed of farmland, pastures, and forests (Table 2). These findings are in agreement with the idea that traditional agro-silvo-pastoral mosaics can host great species richness. According to the hypothesis put forward by Tscharntke et al. (2012), the disturbance effect that decreases $\alpha$-diversity at the plot or farm scale is overridden by a significant increase of $\beta$-diversity at the landscape scale and $\gamma$-diversity at the regional scale. Within these mosaics, both the anthropogenic disturbance and the landscape complexity are kept at intermediate levels. The trade-off established between them leads to the emergent property of having higher $\beta$-diversity than the sum of $\alpha$-diversity (Swift et al. 2004). Hence landscape-wide biodiversity becomes predominant and many species adapt to the heterogeneous mosaics to find resources across habitats.

A sound study of landscape patterns is seldom found in the FT literature. However, even when landscape patterns are taken into account (Meyfroidt and Lambin 2008, 2011), the focus is exclusively on forested habitats. Contrastingly, our analysis simultaneously considered different habitat types or landscape units following a landscape ecological approach to land abandonment (Farina 1997, Preiss et al. 1997, Laiolo et al. 2004, Moreira and Russo 2007) and thus provides a broader view on the likely effects of farmland abandonment on landscape and biodiversity along the forest transition. In so doing, our study might contribute to widen the critical self-reflection on data sources and methods done by FT proponents themselves. In his pioneering work, Mather (1992) already pointed out the inconsistency of forest definitions across nations and regions in the data he used, FAO assessments of the world's forest resources. Later, the use of remote-sensing data resulted in much more consistent estimations and allowed for a differentiation between forest types and biomes (Redo et al. 2012). Still, authors stressed that using forest area alone had severe limitations in diagnosing meaningful changes in forest and territorial sustainability (Bae et al. 2012, Yeo and Huang 2013). The issue at stake is not only whether forest area is recovering spontaneously or through tree plantation, nor the type and quality of the recovering forests. Important as these questions might be, our work shows that forest recovery per se might occur at the expense of other habitats important for biodiversity.

\section{CONCLUSIONS}

We studied the effects of land abandonment on landscape and biodiversity through an in-depth historical case study covering a period of 160 years in a selected Mediterranean area. By using and integrating land-use cadastral data, landscape metrics, and qualitative interviews, we characterized the landscape socialecological changes linked to land abandonment and forest expansion. Rural out-migration and land abandonment were shown to bring about a loss of landscape diversity caused by the disappearance of agro-silvo-pastoral mosaics created by the multiple land-use strategy of local peasants. The local peasant community was shown to shape landscape ecological features mostly as a source of spatial heterogeneity entailing a greater capacity to host biodiversity. Even if varying responses to land abandonment were found for different taxa, biodiversity was shown to be linked to such heterogeneity.

Our results are in agreement with landscape ecologists pointing out that land abandonment and forest expansion homogenize landscape structures in Europe (Preiss et al. 1997, Laiolo et al. 2004, Moreira and Russo 2007). Accordingly, landscape heterogeneity seems a paramount criterion for designing successful biodiversity conservation policies in postabandonment landscapes (Atauri and de Lucio 2001). In turn, landscape heterogeneity was shown to be closely linked to long-term, landuse diversity. However, the socioeconomic conditions underlying past land-use practices are neither viable nor socially desirable. Rather than trying desperately to preserve traditional practices, conservation strategies should be aimed at creating new socialecological interactions that would enhance biodiversity in innovative ways (Fischer et al. 2012). These might include the connection of local farmers to the growing food and energy cooperatives in Barcelona, which favor organic and short distance supply (Conill et al. 2012).

We questioned the alleged relationship between land abandonment and ecosystem recovery, which is at the heart of the forest transition (FT) framework (Aide and Grau 2004, Rudel et al. 2005). By using insights from landscape ecology in a 
historically informed manner, we showed that land abandonment might actually be related to ecosystem degradation. Therefore, our work suggests a remarkable trade-off of forest expansion for biodiversity at local and regional scales that seems worth investigating further. We indicated that the assumed restorative character of the FT is partly based on the underestimation of the ecological importance of nonforest habitats, such as rain-fed farmland, vineyards, and pastureland. Forest expansion itself can occur at the expense of the biodiversity assemblages of such habitats. Thus, we question FT's inherent policy implication, i.e., the withdrawal of productive activities of rural settlers to promote forest and ecosystem recovery (Aide and Grau 2004). On the contrary, as our work suggests, biodiversity conservation in Mediterranean transition forests depends on finding viable ways of reversing the negative effects of rural land abandonment. In spite of our criticism, the FT has proven to be a useful framework to understand the demographic, socioeconomic, and land-use changes occurring in our study area in the context of broader geographic economic processes (Rudel et al. 2005, Lambin and Meyfroidt 2010).

We illustrated both the strengths and challenges of using historical approaches to study the effects of land abandonment on biodiversity. Our historical approach illuminated the complex social-ecological interactions shaping landscape ecological features throughout centuries. This valuable information, however, came at a cost. The information that was integrated, land-use cadastral data, qualitative interviews, and bioindicator species, had mismatching temporal scopes. This meant that we could not know how all parameters changed over the entire study period and to what extent they changed in an interrelated way, especially land uses and bioindicator species populations. This challenge was addressed by discussing the results in a historical narrative in which qualitative and quantitative data of different temporal scopes were integrated into a coherent and meaningful account (Cronon 1992).

Last but not least, we clarified the authors' preanalytical vision. Preanalytical visions play a crucial role in how authors report the effects of land abandonment on biodiversity (Queiroz et al. 2014). However, they are seldom made explicit. Our preanalytical focus on open habitats and landscape heterogeneity might somehow have influenced the study design and our overall negative interpretation of land abandonment. The explicit communication of those things that are usually taken for granted facilitates the dialogue between epistemic communities and thus enhances progress in interdisciplinary research (Nielsen and D'haen 2014).

Responses to this article can be read online at: http://www.ecologyandsociety.org/issues/responses. $\mathrm{php} / 7378$

\section{Acknowledgments:}

The authors thank Anna Badia for initial help with the cadastral map of 1954 and Daniel Rangil for the information on traditional land-management practices. Jonas $\varnothing$. Nielsen provided helpful comments to an earlier draft of the paper. Comments from four anonymous reviewers are greatly appreciated. Feedback from the
IRI-THESys Colloquium of the 23rd May 2014, where this paper was presented, was also very useful. The work was supported by the research project HAR2012-38920-C02-02, Sustainable farm systems and transitions in agricultural metabolism: social inequality and institutional changes in Spain 1750-2010, funded by the Spanish Ministry of Economy and Competitiveness, and the international Partnership Grant SSHRC- 895-2011-1020, Sustainable farm systems: long-term socio-ecological metabolism in western agriculture, funded by the Social Sciences and Humanities Research Council of Canada. I. O. received a grant from the Ministry of Innovation, Universities and Enterprise of the Catalan Government while conducting part of this research (Ref. 2005FI00505).

\section{LITERATURE CITED}

Aide, T. M., and H. R. Grau. 2004. Globalization, migration, and Latin American ecosystems. Science 305:1915-1916. http://dx. doi.org/10.1126/science. 1103179

Anton, M., S. Herrando, and D. Garcia. 2013. El Seguiment d'Ocells Comuns a Catalunya 2013. Programa de seguiment de l'avifauna al Parc de Montnegre-Corredor. Catalan Institute of Ornithology, Barcelona, Spain.

Atauri, J. A., and J. V. de Lucio. 2001. The role of landscape structure in species richness distribution of birds, amphibians, reptiles and lepidopterans in Mediterranean landscapes. Landscape Ecology 16:147-159. http://dx.doi.org/10.1023/ A:1011115921050

Badia-Miró, M., and E. Tello. 2014. Vine-growing in Catalonia: the main agricultural change underlying the earliest industrialization in Mediterranean Europe (1720-1939). European Review of Economic History 18:203-226. http://dx.doi. org/10.1093/ereh/heu006

Bae, J. S., R. W. Joo, and Y.-S. Kim. 2012. Forest transition in South Korea: reality, path and drivers. Land Use Policy 29:198-207. http://dx.doi.org/10.1016/j.landusepol.2011.06.007

Başnou, C., E. Álvarez, G. Bagaria, M. Guardiola, R. Isern, P. Vicente, and J. Pino. 2013. Spatial patterns of land use changes across a Mediterranean metropolitan landscape: implications for biodiversity management. Environmental Management 52:971-980. http://dx.doi.org/10.1007/s00267-013-0150-5

Benton, T. G., J. A. Vickery, and J. D. Wilson. 2003. Farmland biodiversity: is habitat heterogeneity the key? Trends in Ecology and Evolution 18:182-188. http://dx.doi.org/10.1016/S0169-5347 (03)00011-9

Bernard, H. R. 2006. Research methods in anthropology. Qualitative and quantitative approaches. Altamira, Oxford, UK.

Bignal, E. M., and D. I. McCracken. 1996. Low-intensity farming systems in the conservation of the countryside. Journal of Applied Ecology 33:413-424. http://dx.doi.org/10.2307/2404973

Boada, M., 1984. Flora, fauna i plantes remeieres del Baix Montseny-Montnegre. Centre d'Estudis i Documentació del Baix Montseny, Sant Celoni, Barcelona, Spain.

Bombí, A. 2004. El pla de seguiment del Montnegre i el Corredor: estat actual i línies d'actuació prioritàries. Pages 15-18 in M. 
Miralles, S. Santiago, J. Hernàndez, and J. Melero, editors. IV Trobada d'Estudiosos del Montnegre i el Corredor. Diputació de Barcelona, Barcelona, Spain.

Conill, J., A. Cárdenas, M. Castells, S. Hlebik, and L. Servon. 2012. Otra vida es posible: prácticas económicas alternativas durante la crisis. Ediciones UOC, Barcelona, Spain.

Cronon, W. 1992. A place for stories: nature, history, and narrative. Journal of American History 78:1347-1376. http://dx. doi.org/10.2307/2079346

Farina, A. 1997. Landscape structure and breeding bird distribution in a sub-Mediterranean agro-ecosystem. Landscape Ecology 12:365-378. http://dx.doi.org/10.1023/A:1007934518160

Farina, A., A. R. Johnson, S. J. Turner, and A. Belgrano. 2003. 'Full' world versus 'empty' world paradigm at the time of globalisation. Ecological Economics 45:11-18. http://dx.doi. org/10.1016/S0921-8009(02)00255-0

Fischer, J., T. Hartel, and T. Kuemmerle. 2012. Conservation policy in traditional farming landscapes. Conservation Letters 5:167-175. http://dx.doi.org/10.1111/j.1755-263X.2012.00227.x

Franco, A. M. A., and W. J. Sutherland. 2004. Modelling the foraging habitat selection of lesser kestrels: conservation implications of European agricultural policies. Biological Conservation 120:63-74. http://dx.doi.org/10.1016/j.biocon.2004.01.026

Grau, H. R., and T. M. Aide. 2008. Globalization and land-use transitions in Latin America. Ecology and Society 13(2): 16. [online] URL: http://www.ecologyandsociety.org/vol13/iss2/ $\underline{\operatorname{art16/}}$

Gutiérrez, C., 2001. Fitxes tècniques del catàleg de flora vascular d'interès conservacionista. Tàxons prioritaris i tàxons d'especial interès. Montnegre-Corredor Park, Vallgorguina, Spain.

Gutiérrez, C. 2004. Aplicació del pla de conservació de la flora vascular al Parc del Montnegre i el Corredor. Pages 61-65 in M. Miralles, S. Santiago, J. Hernàndez, and J. Melero, editors. IV Trobada d'Estudiosos del Montnegre i el Corredor. Diputació de Barcelona, Barcelona, Spain.

Hole, D. G., A. J. Perkins, J. D. Wilson, I. H. Alexander, P. V. Grice, and A. D. Evans. 2005. Does organic farming benefit biodiversity? Biological Conservation 122:113-130. http://dx.doi. org/10.1016/j.biocon.2004.07.018

International Union for Conservation of Nature (IUCN). 2014. The IUCN red list of threatened species. International Union for Conservation of Nature, Cambridge, UK. [online] URL: http:// www.iucnredlist.org

Jaeger, J. A. G. 2000. Landscape division, splitting index, and effective mesh size: new measures of landscape fragmentation. Landscape Ecology 15:115-130. http://dx.doi.org/10.1023/ A:1008129329289

Laiolo, P., F. Dondero, E. Ciliento, and A. Rolando. 2004. Consequences of pastoral abandonment for the structure and diversity of the alpine avifauna. Journal of Applied Ecology 41:294-304. http://dx.doi.org/10.1111/j.0021-8901.2004.00893.x

Lambin, E. F., and P. Meyfroidt. 2010. Land use transitions: socio-ecological feedback versus socio-economic change. Land Use Policy 27:108-118. http://dx.doi.org/10.1016/j.landusepol.2009.09.003
Macià, F. X., J. Grajera, and X. Larruy. 2013. Bioindicadors de la gestió i l'ús social als parcs del Montnegre i el Corredor, de la Serralada Litoral i de la Serralada de Marina. L'astor, l'àguila marcenca, l'aligot vesper i el duc. Montnegre-Corredor Park, Vallgorguina, Barcelona, Spain. Marull, J., I. Otero, C. Stefanescu, E. Tello, M. Miralles, F. Coll, M. Pons, and G. L. Diana. 2015. Exploring the links between forest transition and landscape changes in the Mediterranean. Does forest recovery really lead to better landscape quality? Agroforestry Systems, in press.

Marull, J., E. Tello, P. T. Wilcox, F. Coll, M. Pons, P. Warde, N. Valldeperas, and A. Ollés. 2014. Recovering the land-use history behind a Mediterranean edge environment (the Congost Valley, Catalonia, 1854-2005): the importance of agroforestry systems in biological conservation. Applied Geography 54:1-17. http://dx. doi.org/10.1016/j.apgeog.2014.06.030

Mather, A. S. 1992. The forest transition. Area 24:367-379.

Meyfroidt, P., and E. F. Lambin. 2011. Global forest transition: prospects for an end to deforestation. Annual Review of Environment and Resource 36:343-371. http://dx.doi.org/10.1146/ annurev-environ-090710-143732

Meyfroidt, P., and E. F. Lambin. 2008. Forest transition in Vietnam and its environmental impacts. Global Change Biology 14:1319-1336. http://dx.doi.org/10.1111/j.1365-2486.2008.01575. $\underline{x}$

Miralles, M., and C. Stefanescu. 2004. Les papallones diürnes del Montnegre. Deu anys de seguiment amb la metodologia del BMS. Pages 105-112 in M. Miralles, S. Santiago, J. Hernàndez, and J. Melero, editors. IV Trobada d'Estudiosos del Montnegre i el Corredor. Diputació de Barcelona, Barcelona, Spain.

Montserrat, P. 1989, c1955-1964. Flora de la cordillera litoral catalana (porción comprendida entre los ríos Besós y Tordera). Caixa d'Estalvis Laietana, Mataró, Spain.

Moreira, F., and D. Russo. 2007. Modelling the impact of agricultural abandonment and wildfires on vertebrate diversity in Mediterranean Europe. Landscape Ecology 22:1461-1476. http:// dx.doi.org/10.1007/s10980-007-9125-3

Moser, B., J. A. G. Jaeger, U. Tappeiner, E. Tasser, and B. Eiselt. 2007. Modification of the effective mesh size for measuring landscape fragmentation to solve the boundary problem. Landscape Ecology 22:447-459. http://dx.doi.org/10.1007/ s10980-006-9023-0

Nadal, F., L. Urteaga, and J. I. Muro. 2005. La documentación cartográfica de la contribución de inmuebles, cultivo y ganadería: el caso de la provincia de Barcelona (1845-1895). Boletín de la Asociación de Geógrafos Españoles 40:83-109.

Navarro, L. M., and H. M. Pereira. 2012. Rewilding abandoned landscapes in Europe. Ecosystems 15:900-912. http://dx.doi. org/10.1007/s10021-012-9558-7

Nielsen, J. Ø., and S. A. L. D’haen. 2014. Asking about climate change: reflections on methodology in qualitative climate change research published in Global Environmental Change since 2000. Global Environmental Change 24:402-409. http://dx.doi. org/10.1016/j.gloenvcha.2013.10.006 
Otero, I. 2010. The rural-urban socioecological transformation of Mediterranean mountain areas under global change. Local studies in Olzinelles and Matadepera (Barcelona Metropolitan Region). Dissertation. Universitat Autònoma de Barcelona, Barcelona, Spain.

Otero, I., and M. Boada. 2012. El patrimoni socioecològic de la pagesia. L'exemple d'Olzinelles, al massís del Montnegre (Serralada Litoral). Publicacions de l'Abadia de Montserrat, Barcelona, Spain.

Otero, I., M. Boada, A. Badia, and S. Piqueras. 2008. El canvi global a la conca de la Tordera. Pages 95-129 in M. Boada, S. Mayo, and R. Maneja, editors. Els sistemes socioecològics de la conca de la Tordera. Institució Catalana d'Història Natural, Barcelona, Spain.

Otero, I., M. Boada, A. Badia, E. Pla, J. Vayreda, S. Sabaté, C. A. Gracia, and J. Peñuelas. 2011. Loss of water availability and stream biodiversity under land abandonment and climate change in a Mediterranean catchment (Olzinelles, NE Spain). Land Use Policy 28:207-218. http://dx.doi.org/10.1016/j.landusepol.2010.06.002

Otero, I., M. Boada, J. D. Tàbara. 2013. Social-ecological heritage and the conservation of Mediterranean landscapes under global change. A case study in Olzinelles (Catalonia). Land Use Policy 30:25-37. http://dx.doi.org/10.1016/j.landusepol.2012.02.005

Pagès, J., C. Gutiérrez, and J. Mora. 2005. Avis savis: en pepito de can pau foguera. La Vall 282:9-15.

Parcerisas, L., J. Marull, J. Pino, E. Tello, F. Coll, and C. Basnou. 2012. Land use changes, landscape ecology and their socioeconomic driving forces in the Spanish Mediterranean coast (El Maresme County, 1850-2005). Environmental Science and Policy 23:123-32. http://dx.doi.org/10.1016/j.envsci.2012.08.002

Piqueras, S., 2009. Manifestacions del canvi global. Anàlisi socioecològica dels canvis en els usos i les cobertes del sòl a la vall de Sant Martí de Montnegre-Vilardell (1853-2007). Thesis. Universitat Autònoma de Barcelona, Barcelona, Spain.

Portals, J. 1998. El Montnegre, una història de mil anys. Els llibres del Set-ciències, Arenys de Mar, Barcelona, Spain.

Preiss, E., J.-L. Martin, and M. Debussche. 1997. Rural depopulation and recent landscape changes in a Mediterranean region: consequences to the breeding avifauna. Landscape Ecology 12:51-61. http://dx.doi.org/10.1007/BF02698207

Queiroz, C., R. Beilin, C. Folke, and R. Lindborg. 2014. Farmland abandonment: threat or opportunity for biodiversity conservation? A global review. Frontiers in Ecology and the Environment 12:288-296. http://dx.doi.org/10.1890/120348

Redo, D. J., H. R. Grau, T. M. Aide, M. L. Clark. 2012. Asymmetric forest transition driven by the interaction of socioeconomic development and environmental heterogeneity in Central America. Proceedings of the Natural Academy of Sciences 109:8839-8844. http://dx.doi.org/10.1073/pnas.1201664109

Ribas, J., and X. Pons. 2001. Estudi de la distribució i abundància dels poblaments avifaunístics del Montnegre i el Corredor. Pages 35-43 in III Trobada d'estudiosos del Montnegre i el Corredor. Diputació de Barcelona, Barcelona, Spain.
Rosell, C. 1998. Biologia i ecologia del senglar (Sus scrofa $L$. , 1758) a dues poblacions del nordest ibèric. Aplicació a la gestió. Dissertation. Universitat de Barcelona, Barcelona, Spain.

Rosell, C., and F. Navàs. 2014. Programa de seguiment de les poblacions de senglar a Catalunya. Montnegre i el Corredor Temporada 2013/2014. Informe per a les colles participants. Montnegre-Corredor Park, Vallgorguina, Barcelona, Spain.

Rudel, T. K., O. T. Coomes, E. Moran, F. Achard, A. Angelsen, J. Xu, and E. Lambin. 2005. Forest transitions: towards a global understanding of land use change. Global Environmental Change 15:23-31. http://dx.doi.org/10.1016/j.gloenvcha.2004.11.001

Sáez, L., and I. Soriano. 2000. Catàleg de plantes vasculars endèmiques, rares o amenaçades de Catalunya. II. Tàxons no endèmics en situació de risc. Butlletí de la Institució Catalana d'Història Natural 68:35-50.

Swift, M. J., A.-M. N. Izac, and M. van Noordwijk. 2004. Biodiversity and ecosystems services in agricultural landscapes are we asking the right questions? Agriculture, Ecosystems and Environment 104:113-134. http://dx.doi.org/10.1016/j.agee.2004.01.013

Tscharntke, T., J. M. Tylianakis, T. A. Rand, R. K. Didham, L. Fahring, P. Batáry, J. Bengtsson, Y. Clough, T. O. Crist, C. F. Dormann, R. M. Ewers, J. Fründ, R. D. Holt, A. Holzschuh, A. M. Klein, D. Kleijn, C. Kremen, D. A. Landis, W. Laurance, D. Lindenmayer, C. Scherber, N. Sodhi, I. Steffan-Dewenter, C. Thies, W. H. van der Putten, and C. Westphal. 2012. Landscape moderation of biodiversity patterns and processes - eight hypotheses. Biological Reviews 87:661-685. http://dx.doi. org/10.1111/j.1469-185X.2011.00216.X

Urteaga, L., and F. Nadal. 2013. Los aprovechamientos forestales en las sierras del Corredor y el Montnegre a mediados del siglo XIX. Boletín de la Asociación de Geógrafos Españoles 62:237-263.

Walker, R. 2012. The scale of forest transition: Amazonia and the Atlantic forests of Brazil. Applied Geography 32:12-20. http://dx. doi.org/10.1016/j.apgeog.2010.10.010

Yeo, I.-Y., and C. Huang. 2013. Revisiting the forest transition theory with historical records and geospatial data: a case study from Mississippi (USA). Land Use Policy 32:1-13. http://dx.doi. org/10.1016/j.landusepol.2012.09.017

Yin, R. K., 2003. Case study research: design and methods. Sage, Thousand Oaks, California, USA. 
Appendix 1. Land uses, management practices, and related habitats and species in farmland and pastureland (ca. 1900-1950). Source: land uses and management practices from interviews (see methods); habitats and species from Montserrat ([1955-1964] 1989), Boada (1984), Otero (2010), Otero et al. (2011) and interviewees \#3, 5, 10. Management practices of stabled livestock are excluded (see Otero et al. 2013 for a complete account).

\begin{tabular}{|c|c|c|c|}
\hline Land cover & Land uses and management practices & Habitats & Species \\
\hline $\begin{array}{l}\text { Irrigated } \\
\text { farmland }\end{array}$ & $\begin{array}{l}\text { - Cultivating vegetables for self-supply and } \\
\text { livestock. } \\
\text { - Collecting and storing water for irrigation } \\
\text { in weirs, ditches, pools, and ponds. }\end{array}$ & $\begin{array}{l}\text { Permanent } \\
\text { water bodies }\end{array}$ & $\begin{array}{l}\text { - Ponds were breeding sites for amphibians: Parsley Frog } \\
\text { (Pelodytes punctatus), Fire Salamander (Salamandra } \\
\text { salamandra), and Marbled Newt (Triturus marmoratus). } \\
\text { - Weirs helped maintain fish populations in ephemeral } \\
\text { streams: Mediterranean barbel (Barbus meridionalis), chub } \\
\text { (Squalius cephalus), and European eel (Anguilla anguilla). }\end{array}$ \\
\hline \multirow[t]{5}{*}{$\begin{array}{l}\text { Rain-fed } \\
\text { farmland }\end{array}$} & $\begin{array}{l}\text { - Terracing slopes. } \\
\text { - Preserving terraces by means of stone } \\
\text { walls. } \\
\text { - Planting trees, shrubs, fruit trees, and } \\
\text { vines in field edges. }\end{array}$ & $\begin{array}{l}\text { Stone walls and } \\
\text { edges }\end{array}$ & $\begin{array}{l}\text { Refuges and feeding areas for reptile species, e.g. Ocellated } \\
\text { Lizard (Timon lepidus). }\end{array}$ \\
\hline & \multirow[t]{2}{*}{$\begin{array}{l}\text { - Cultivating wheat for bread self-supply: } \\
\text { ploughing, sowing, hoeing, and harvesting. } \\
\text { - Cultivating oats, barley, lucerne, maize, } \\
\text { and sorghum for livestock. } \\
\text { - Soil fertility maintained through animal } \\
\text { manure, crop rotation, and green manure. }\end{array}$} & Cereal fields & $\begin{array}{l}\text { - Foraging sites for granivore birds such as Crested Lark } \\
\text { (Galerida cristata), Skylark (Alauda arvensis), and Corn } \\
\text { Bunting (Miliaria calandra). } \\
\text { - Nesting ground for some bird species (e.g. Red-legged } \\
\text { Partridge, Alectoris rufa). }\end{array}$ \\
\hline & & Short grasses & $\begin{array}{l}\text { Spontaneous grasses in field margins: Brachypodium } \\
\text { ramosum; B. distachyum; B. phoenicoides; Dactylis } \\
\text { glomerata ssp. hispanica; Poa annua. }\end{array}$ \\
\hline & $\begin{array}{l}\text { - Cultivating olive trees for oil self-supply } \\
\text { and trading. }\end{array}$ & Olive groves & \\
\hline & $\begin{array}{l}\text { - Cultivating fruit trees for self-supply as } \\
\text { secondary crops. }\end{array}$ & Orchards & $\begin{array}{l}\text { Trunks of fruit trees provided nests for some bird species, } \\
\text { e.g. the Eurasian wryneck (Jynx torquilla) nested in split } \\
\text { trunks of fig trees. }\end{array}$ \\
\hline Vineyard & $\begin{array}{l}\text { - Cultivating vine for wine self-supply and } \\
\text { trading. } \\
\text { - Pruning, fertilizing, ploughing, grafting } \\
\text { vines, hoeing, fumigating with sulfur and } \\
\text { copper sulfate, harvesting. } \\
\text { - Cultivation on steep slopes without } \\
\text { terracing. } \\
\text { - Controlling soil erosion by zigzag } \\
\text { drainage ditches. } \\
\text { - Cultivating medicinal and aromatic } \\
\text { plants, fruit trees, and fodders as secondary } \\
\text { crops. } \\
\text { - Conserving soil fertility: animal manure } \\
\text { and green manure. }\end{array}$ & $\begin{array}{l}\text { Slopes with } \\
\text { sparse vines and } \\
\text { low plant cover, } \\
\text { including some } \\
\text { shrubs and } \\
\text { grasses }\end{array}$ & $\begin{array}{l}\text { - Reptiles species like Psammodromus jeanneae, Ladder } \\
\text { Snake (Rhinechis scalaris), Montpellier Snake (Malpolon } \\
\text { monspessulanus), Southern Smooth Snake (Coronella } \\
\text { girondica), and Ocellated Lizard (Timon lepidus) were found } \\
\text { in vineyards. Some benefited from low plant cover to } \\
\text { sunbathe or used stone walls to hide. } \\
\text { - Some bird species like the Red-legged Partridge (Alectoris } \\
\text { rufa) fed on spontaneous grasses germinating between } \\
\text { hoeing works. }\end{array}$ \\
\hline \multirow[t]{2}{*}{ Pastureland } & \multirow{2}{*}{$\begin{array}{l}\text { - Fattening pigs for trading: herds of } 100 \text { to } \\
200 \text { heads grazing acorns and roots in } \\
\text { Holm Oak and Cork Oak forests and on } \\
\text { wastelands. } \\
\text { - Raising sheep and goats for trading: } \\
\text { flocks of } 200 \text { to } 400 \text { heads grazing herbs, } \\
\text { stems, shrubs, shoots, lower branches of } \\
\text { trees and acorns in Holm Oak and Cork } \\
\text { Oak forests, wastelands, meadows, and } \\
\text { stubble fields. }\end{array}$} & $\begin{array}{l}\text { Meadows, } \\
\text { pastures and } \\
\text { scrublands }\end{array}$ & $\begin{array}{l}\text { Wet meadows included grasses such as Festuca } \\
\text { arundinacea. F. rubra formed pastures together with } \\
\text { Bromus erectus or Dactylis glomerata ssp. glomerata. Drier } \\
\text { pastures included herbs such as Hyparrhenia hirta and } H \text {. } \\
\text { pubescens. }\end{array}$ \\
\hline & & $\begin{array}{l}\text { Holm and Cork } \\
\text { Oak forests } \\
\text { with low to } \\
\text { medium canopy } \\
\text { cover }\end{array}$ & See table 9. \\
\hline
\end{tabular}


Appendix 2. Land uses, management practices, and related habitats and species in forests (ca. 19001950). Source: land uses and management practices from interviews (see methods); habitats and species from Montserrat ([1955-1964] 1989), Gutiérrez (2001), and Otero et al. (2011).

\begin{tabular}{|c|c|c|c|}
\hline Forest type & Land uses and management practices & Habitats & Species \\
\hline \multirow[t]{3}{*}{$\begin{array}{l}\text { Cork Oak } \\
\text { and Holm } \\
\text { Oak } \\
\text { (Quercus } \\
\text { suber and Q. } \\
\text { ilex) }\end{array}$} & $\begin{array}{l}\text { - Coppice selection every 7-10 years with complete cycles of } \\
21 \text {-30 years. } \\
\text { - Initial sprout selection down to } 4 \text { sprouts per stump 5-6 years } \\
\text { after coppicing. } \\
\text { - Final sprout selection down to } 2 \text { sprouts per stump. } \\
\text { - Felling competitor species such as Pinus pinea and Quercus } \\
\text { humilis. } \\
\text { - Periodical selective slashing of bushes (e.g. Erica arborea, } \\
\text { Rubus ulmifolius) while conserving soil-improving leguminosae } \\
\text { species (e.g. Ulex parviflorus). } \\
\text { - Felling E. arborea and Arbutus unedo; uprooting their stumps. } \\
\text { - Cork debarking every } 14-17 \text { years. } \\
\text { - Grazing by pig herds and sheep flocks. }\end{array}$ & \begin{tabular}{|l|} 
Cork Oak and \\
Holm Oak \\
forests with \\
medium \\
canopy cover
\end{tabular} & $\begin{array}{l}\text { Some plant species indicated the } \\
\text { existence of clearings, areas with low } \\
\text { canopy cover, scrublands and open rocky } \\
\text { grounds within forests: Erica cinerea, } \\
\text { Helianthemum tuberaria, and Orobanche } \\
\text { teucrii. }\end{array}$ \\
\hline & $\begin{array}{l}\text { - Charcoal making in earth-covered firewood piles. } \\
\text { - Fine charcoal making through the heating of brushwood in } \\
\text { kilns, pits, or piles. }\end{array}$ & $\begin{array}{l}\text { Burnt earth } \\
\text { and charcoal } \\
\text { residues }\end{array}$ & $\begin{array}{l}\text { Geranium lanuginosum, a very rare plant } \\
\text { throughout Catalonia, was found in forest } \\
\text { clearings shortly after the burning of } \\
\text { firewood piles for charcoal production. } \\
\text { Stachys alpina was also particularly } \\
\text { related to charcoal residues. }\end{array}$ \\
\hline & Cultivating fodders, cereals, and vegetables. & \begin{tabular}{|l|} 
Meadows, \\
cereal fields \\
and gardens \\
within forests
\end{tabular} & \\
\hline \multirow[t]{2}{*}{ Riverside } & $\begin{array}{l}\text { Layout of species according to their need of water, from the river } \\
\text { to the outside: Alnus glutinosa, Populus sp., Platanus sp. }\end{array}$ & \multirow{2}{*}{$\begin{array}{l}\text { Riparian } \\
\text { forests } \\
\text { including } \\
\text { both } \\
\text { spontaneous } \\
\text { and planted } \\
\text { tree species as } \\
\text { well as } \\
\text { gardens }\end{array}$} & \multirow{2}{*}{$\begin{array}{l}\text { - Pastures of Festuca rubra and Dactylis } \\
\text { glomerata ssp. Glomerata occurred in } \\
\text { forests with Alnus glutinosa and Populus } \\
\text { sp. } \\
\text { - The Southern Water Vole (Arvicola } \\
\text { sapidus) used to hide under the } \\
\text { submerged roots of alders (A. glutinosa) } \\
\text { and excavated galleries on the slopes of } \\
\text { the streams. }\end{array}$} \\
\hline & $\begin{array}{l}\text { Plantations of Plane Tree (Platanus sp.) } \\
\text { - Planting saplings and felling after } 2 \text { years. } \\
\text { - Sprout selection down to 1-2 sprouts per stump. } \\
\text { - Pruning. } \\
\text { - Felling (rotation of } 20 \text { years). } \\
\text { - Cultivating vegetables for self-supply and livestock within } \\
\text { young plantations. }\end{array}$ & & \\
\hline $\begin{array}{l}\text { Pine (Pinus } \\
\text { sp.) }\end{array}$ & $\begin{array}{l}\text { - Pruning of lower branches (Pinus pinea). } \\
\text { - Felling with different rotations according to species ( } P \text {. pinea, } \\
P \text {. pinaster, } P \text {. insignis, and } P \text {. halepensis). }\end{array}$ & Pine groves & \\
\hline $\begin{array}{l}\text { Chestnut } \\
\text { (Castanea } \\
\text { sativa) }\end{array}$ & $\begin{array}{l}\text { - Sowing chestnuts or planting striplings after forest clearing. } \\
\text { - Felling after } 14-15 \text { years. } \\
\text { - Sprout selection down to } 2-4 \text { sprouts per stump. } \\
\text { - Felling (10-20 years rotation). }\end{array}$ & $\begin{array}{l}\text { Chestnut } \\
\text { groves }\end{array}$ & \\
\hline
\end{tabular}

